MARIA ŚWIDERSKA-BRÓŹ *

\title{
REMOVAL OF HUMIC SUBSTANCES BY COAGULATION
}

The efficiency of humic acid removal by coagulation and 2-hour sedimentation was studied. The investigations also included determination of optimum $\mathrm{pH}$ for removing humic and fulvic acids from aqueous solutions $(\mathrm{pH}=6.0$ or $>10.0)$. The experiments show that 1) ferric sulphate is less efficient than alum, and 2) $\mathrm{Al}^{3+}$ and $\mathrm{Fe}^{3+}$ act as coagulants and coordinating ions for metal-organic complexes and are removed together with humic acids.

\section{NOTATION}

$\mathrm{Al}_{k}^{3+}$ - residual concentration of aluminium ions,

$B$ - coloured matter $\left[\mathrm{g} \mathrm{Pt} / \mathrm{m}^{3}\right]$,

$B_{k} \quad$ - residual coloured matter (colour of water after treatment) $\left[\mathrm{g} \mathrm{Pt} / \mathrm{m}^{3}\right]$,

$D_{c}$ - coagulant dose $\left[\mathrm{g} / \mathrm{m}^{3}\right]$,

ECC - effective consumption of coagulant,

$\mathrm{Fe}_{k}^{3+}$ - residual concentration of ferric ions,

FA - fulvic acids,

HA - humic acids,

ifp - isolated from peat,

pa - pure for analysis,

$p$ - probability [\%],

$r \quad$ - correlation index,

$\eta$ - efficiency of pollutants removal [\%],

$\mathrm{HA}_{k}$ - residual concentration of humic acids.

\section{INTRODUCTION}

The importance of removing humic matter from natural waters is substantiated by many different factors. Humic substances, apart from their contribution to the increase of coloured matter and permanganate COD, exhibit particular sorbability and chemical activity towards some other compounds occurring in the water. Thus, the presence of humic substances brings about

* Institute of Environment Protection Engineering, Technical University of Wroclaw, pl. Grunwaldzki 9, 50-377 Wrocław, Poland. 
a. sorption of both organic and inorganic matter, as well as a stabilization of natural colloids. Humic substances combine with metal ions (and also with heavy-metal ions) to form metal-organic, mostly water-soluble complexes. In the presence of humic substances, chlorine compounds which are widely applied to water treatment produce trichloromethane, a highly noxious organic compound. To achieve the desired water quality, it is necessary to ensure a complete removal of humies in the course of the treatment process prior to chlorination.

\section{CHARACTERIZATION OF HUMIC SUBSTANCES}

Humic substances originate predominantly in soils due to the biochemical transformation of some organies, mostly of vegetal origin. These are high-molecular-weight compounds, which contain many amine acids, hexasoamines, aliphatic chains, aromatic systems and functional groups $-\mathrm{COOH},-\mathrm{OH}-$ phenol; $-\mathrm{OH}-$ alcohol; carboxyl; methoxyl and quinone [13], [15]. The number of functional groups accounts for the acidic properties and the exchange capacity of humic acids. Despite numerous investigations on their structure, no adequate structural formulae describing the humic fractions or the properties of humic acids have been determined so far.

Humic acids, soluble in aqueous solutions of alkalies, sodium oxalate and sodium fluoride [8], [15], belong to the best known compounds of this group. Their molecular weight varies from 2000 (for high-solubility forms) to 50,000 (for forms with lower solubility). They are polymers consisting of monomers which are built of microstructural units. Their structure, however, is still far from being sufficiently well known.

Fulvic acids dissolve in water, alkalies, alcohol and mineral acids [8], [15]. They show a brighter colour, a lower carbon content $(<55 \%)$ and a higher oxygen concentration than do humic acids. According to MEcH' [15], their average molecular weight ranges from 3000 to 6000 , approaching that of the lowest molecular-weight fractions of humic acids. They also consist of the samo microstructural units, but have a less developed nucleus and are characterized by the majority of side chains [15]. Both fulvic and humic acids are polybasic acids, having their equivalent points at $\mathrm{pH}$ between 8 and 9 .

Hymatomelanic acids are defined as a water-insoluble fraction of humus. KoNoNowa [8] says that hymatomelanic acid is an alcohol-soluble fraction of humic acids. SPRENGEL [via 8] suggests that there are water-insoluble humins which ought to be situated between humic acids and carbon.

Apart from the humic fractions listed above, there have been isolated bitu- 
minous humic fractions [15] which are dissolved either in ether or in a 1:1 mixture of alcohol and benzene. These substances consist of saturated and unsaturated hydrocarbons and alcohols; they also contain small amounts of aromatic compounds and acids.

\section{OCCURRENCE OF HUMIC COMPOUNDS IN NATURAL WATERS}

Humic substances - as it has already been mentioned - are natural organic pollutants originating predominantly from the soils of the catchment area. Their concentration depends on the geochemical conditions that occur in the given region. In natural waters with no sewage discharge, humic substances account for the organic pollution level and colour intensity. They occur either in dissolved or colloidal forms, or as insoluble admixtures depending on $\mathrm{pH}$ conditions. At acidic or neutral pH, they form negative colloids, being dissociated in an alkaline medium. NARKIS and REBHUN [13] report that $\mathrm{H}^{+}$ions from the $-\mathrm{OH}$ groups dissociate at $\mathrm{pH}>8.0$ and $\mathrm{H}^{+}$ions from the $-\mathrm{COOH}$ groups begin to dissociate at $\mathrm{pH} 4.6$ to 4.9 .

Fulvic acids are dominant in surface waters. The results of investigations obtained by BLACK [13] showed that fulvic acids, hymatomelanic acids and humic acids accounted for $87 \%, 11 \%$ and $2 \%$, respectively, of the total amount of the humic acids measured. Similar results are reported by PACKHAM [13] and BREemen [3]. The author's own investigations on the occurence of humic aeids in the Odra river water in Poland (carried out over the period of 1980 to 1982 ) showed that their content amounted to $3.5 \mathrm{~g} / \mathrm{m}^{3}$, the fraction of fulvic acids ranging between 15 and $50 \%$.

Conoentrations of humic acids are correlated with the chemical oxygen demand of the water tested. This correlation is described by the following expression:

$$
\mathrm{COD}_{\text {perm }}=2.78[\text { humic acids }]+5.36\left[\mathrm{gO}_{2} / \mathrm{m}^{3}\right] \text {. }
$$

LEIDNER et al. [11] indicate that the quantity of high-molecular organics (humic substances included) in groundwater is considerably lower than in surface water. Bubozor [1] found that humic acid concentrations in groundwater varied from 2.1 to $255 \mathrm{~g} / \mathrm{m}^{3}$, whereas those in surface water ranged from 3.9 to $4.9 \mathrm{~g} / \mathrm{m}^{3}$. Thus, fulvic acids are dominant in surface water, while humic and hymatomelanic acids in groundwater [2]-[4].

\section{REMOVAL OF HUMIC SUBSTANCES FROM AQUEOUS SOLUTIONS}

The so far investigations have been performed to substantiate the utility of coagulation, sorption and oxidation in removing humic substances. Considering the nature of the substances to be removed, cation-polyelectrolyte coa- 
gulation [7], as well as coagulation processes involving hydrolyzing coagulants $[2],[3],[6],[12],[13]$ were found to be the most effective. The course and the efficiency of coagulation depend on $\mathrm{pH}$, initial concentration of humic matter, coagulant dose and type of coagulant. Opinions on the efficiency of alum and ferric coagulant diverge greatly. BreEmen [3] claims that the effectiveness of aluminium sulphate, ferric sulphate and polymeric alum chloride are comparable. BLACK et al. [2] believe (contrary to the opinion of many investigators) that coloured matter may be easier removed by the application of iron salts than by aluminium salts.

According to BLACK and HABERER [2], [6], the optimum pH for the coagulation of negative organic colloids varies from 5 to 6 , when alum is applied as coagulant, ranging from 5 to 6 or from 3.44 to 3.80 or being greater than 9.0 for a ferric coagulant. The results of the investigations on the removal of organics from the Odra river water in Poland [10] indicate that for an effective alum and ferric-salt coagulation process the optimum $\mathrm{pH}$ falls between 4.9 and 6.25 . If the optimum $\mathrm{pH}$ range is maintained, favourable conditions may be established both for the destabilization of organic colloids by $\mathrm{Fe}^{3+}$ and $\mathrm{Al}^{3+}$ ions and for the sorption of pollutants aggregated on $\mathrm{Fe}(\mathrm{OH})_{3}$ and $\mathrm{Al}(\mathrm{OH})_{3}$ flocs. At $\mathrm{pH}$ greater than 7.0 larger coagulant doses should be applied, then, however, the coagulation efficiencies are lower than those obtained at the optimum $\mathrm{pH}$.

Another process recommended for removing humic substances, but still far from being well understood, is sorption on activated carbon. The process is also $\mathrm{pH}$-dependent [5]; $\mathrm{pH}$ accounts for the forms in which humic substances occur. With the increasing concentration of $\mathrm{H}^{+}$ions, the removal of humic acids increases due to the decrease of their solubility. When $\mathrm{pH}$ is kept on a constant level, the efficiency of the process increases with the increasing molecular weight [5]. Oxidation of humic substances with chlorine or ozone [3], [4], [13] brings about the conversion of humic acids to fulvic acids, thus contributing to the decrease of the colour intensity. However, the removal efficiency obtained in this way seems to be doubtful, because the oxidation process yields only the transformation of the humic substances not being accompanied by any removal. Oxidation applied prior to successive technological processes may produce serious trouble in removing these organic pollutants due to water solubility of fulvic acids. Oxidation with chlorine compounds yields chloroform which is toxic. Thus, oxidation should not be thought of as a method for humic substance removal. If such an oxidation is necessary, it ought to follow the removal of the precursors of trihalomethanes or - as Rock and his co-workers believe [7] - chloroform.

\section{REMOVAL OF HUMIC ACIDS BY COAGULATION}

The experiments involved water samples from the Odra river and model solutions enriched with humic acids either pure for analysis (pa) or isolated 
from peat (ifp). Concentrations of pa and ifp humic acids in model solutions (fraction soluble in an alkaline medium) were approximately $90 \%$ and $75 \%$, respectively. Alum and ferric salts used as coagulants were dosed to water at a natural pH or after its adjustment.

The efficiencies of these coagulants were determined after coagulation and 2-hour sedimentation. Alum was used at $\mathrm{pH}>7.0$ (which is not recommended for this coagulant), because of the need of determining the effect of humus substances on the solubility of $\mathrm{Al}(\mathrm{III})$ hydrolysis products at high concentrations of $\mathrm{OH}-$ ions. Considering the affinity of $\mathrm{Al}^{3+}$ and $\mathrm{Fe}^{3+}$ ions for humic acids, the relationship between the residual concentrations of these components were determined.

\subsection{INFLUENCE OF THE KIND AND THE DOSE OF COAGULANT}

Experimental solutions containing pa or ifp humic acids were treated with alum or ferric sulphate doses of 100 or $120 \mathrm{ppm}$ each. The coagulation results and the concentration of $\mathrm{Fe}^{3+}$ ions remaining in the treated water showed that ferric sulphate (in particular in removal of coloured matter) was less effective due to the formation of coloured ferric-organic chelates. Residual concentration decreased with the increasing coagulant dose and process efficiency. KowAL and KoWALSKI [9], who had investigated the coagulation of water samples collected from the Odra river, showed that the ferric coagulant $\left(\mathrm{FeCl}_{3}\right.$. - $6 \mathrm{H}_{2} \mathrm{O}$ ) was less efficient than alum. Ferric chloride doses equal to, or less than, $60 \mathrm{~g} / \mathrm{m}^{3}$ yielded a lower removal of colour than did the same alum doses. The efficiencies of the two coagulants became comparable as the dose of ferric chloride increased to $80-120 \mathrm{~g} / \mathrm{m}^{3}$, due to the decrease of $\mathrm{pH}$ value to 6.0 ; this value being optimal for the coagulation of organic colloids.

The removal degrees for pa humic acids, coloured matter and $\mathrm{COD}_{\text {perm }}$ were proportional to the coagulant doses applied. At optimal doses (about

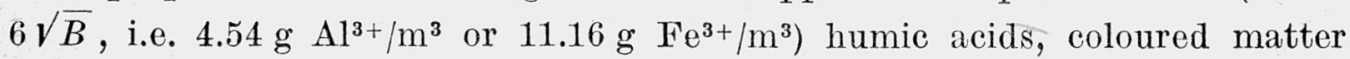
and $\mathrm{COD}_{\text {perm }}$ decreased, being: $<1.0 \mathrm{~g} / \mathrm{m}^{3}, 20 \mathrm{~g} \mathrm{Pt} / \mathrm{m}^{3}$ and $2.5 \mathrm{~g} \mathrm{O}_{2} / \mathrm{m}^{3}$, respectively. For aqueous solutions containing ifp humic acids the optimal alum dose $\left(\mathrm{Al}_{2}\left(\mathrm{SO}_{4}\right)_{3} \cdot 18 \mathrm{H}_{2} \mathrm{O}\right)$ was higher and amounted to $8 \sqrt{B}$, i.e. $8.1 \mathrm{~g} \mathrm{Al} \mathrm{Al}^{3+} / \mathrm{m}^{3}$. The Tncrease of the $\mathrm{Fe}_{2}\left(\mathrm{SO}_{4}\right)_{3} \cdot 9 \mathrm{H}_{2} \mathrm{O}$ dose to the level of $8 \sqrt{B}$ yielded neither the colour removal required $\left(B_{k}=35 \mathrm{~g} \mathrm{Pt} / \mathrm{m}^{3}\right)$ nor a sufficient removal of humic acids, which was lower than that achieved with the alum coagulant. This might be due to the fact that the content of fulvic acids in the ifp humic acids was higher than in the pfa humic acids. From the results obtained it follows that organics are removed more efficiently by alum than ferric salts. This higher efficiency of alum is also indicated by the measured values of the effective consumption of coagulant (ECC) listed in the table. 
Table

Effective consumption of alum or ferric sulphate for removal of colour, $\mathrm{COD}_{\text {perm }}$ and humic acids

Wykorzystanie siarczanu glinowego lub żelazowego podczas obniżania intensywności barwy, usuwania utlenialności nadmanganianowej i kwasów humusowych

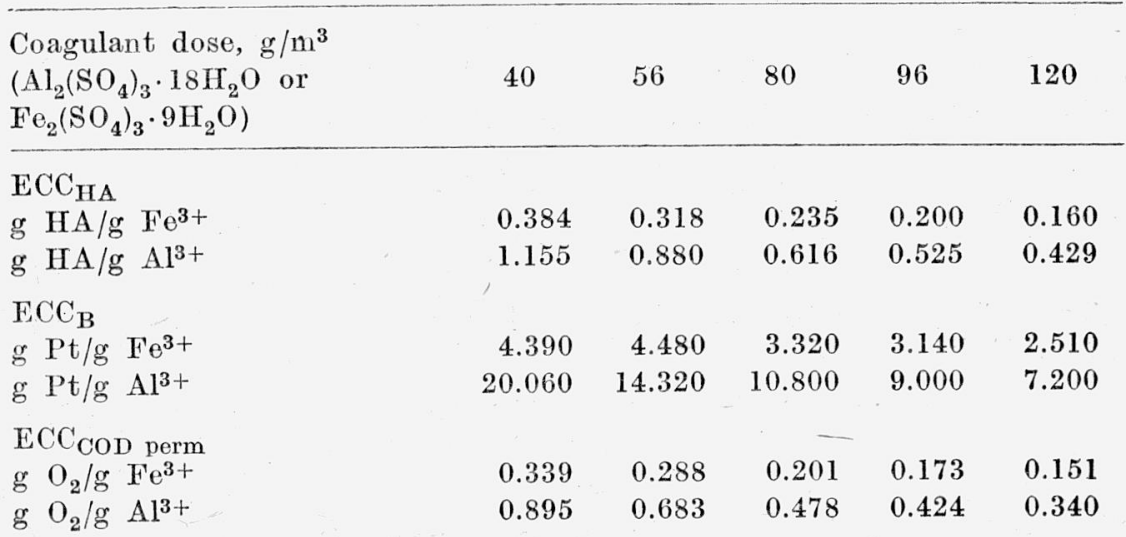

The influence of $\mathrm{H}^{+}$ions concentration on the course and efficiency of the coagulation process was determined by analyzing aqueous solutions which contained approximately $9.0 \mathrm{~g}$ pa humic acids $/ \mathrm{m}^{3}$, their $\mathrm{pH}$ after adjustment ranged from 3.0 to about 12.0. From the data plotted in fig. 1 it follows that for the coagulation of organics the optimum $\mathrm{pH}$ is 6.0 and 5.3 for alum and ferric sulphate, respectively. At these $\mathrm{pH}$, good removal efficiencies were obtained for coloured matter and $\mathrm{COD}_{\text {perm }}$ (standard values for tap and household water), the residual concentration of humic acids being $\ll 1.0 \mathrm{~g} / \mathrm{m}^{3}$. Similar removal efficieney was achieved with ferric sulphate, ferric chloride and ferric nitrate at $\mathrm{pH}=6.05$.

The high efficiency of the coagulation process at an optimum $\mathrm{H}^{+}$ion concentration is due to the electrostatic reaction that occurs either between organic colloids and positive ions $\left(\mathrm{Fe}^{3+}\right.$ or $\left.\mathrm{Al}^{3+}\right)$ or between organics and alum or irom compounds (e. g. $\mathrm{Fe}(\mathrm{OH})_{2}^{+}, \mathrm{Al}(\mathrm{OH})_{2}^{+}$), which are then effectively sorbed on $\mathrm{Al}\left(\mathrm{OH}_{3}\right)$ or $\left.\mathrm{Fe}(\mathrm{OH})_{3}\right)$ flocs and removed from the solution by sedimentation. The decrease of humic acids and coloured matter concentration achieved at a $\mathrm{pH}$ of about 3.0 in the presence of a ferric coagulant may be attributed to the precipitation of humic and hymatomelanic acids. The application of $\mathrm{pH}$ higher than 10 brings about a considerable increase of the coagulation efficiency which is mainly caused by a co-prceipitation of humic substances, magnesium 
hydroxide and calcium carbonate. A similar relationship was determined by the author of this report in a study on the contribution pf $\mathrm{pH}$ adjustment to the efficiency of humic acids removal [14]. The decrease of the process effectiveness at a natural $\mathrm{pH}$ may be due to the stability of organic colloids.

The coagulation effects achieved with different coagulant doses at $\mathrm{pH}$ of about 6.0 are given in fig. 2. As shown by this figure, at optimal concentration of $\mathrm{H}^{+}$ions lower doses of coagulant (both alum and ferric sulphate) may be applied. For model solutions alum and ferric sulphate demands (determined

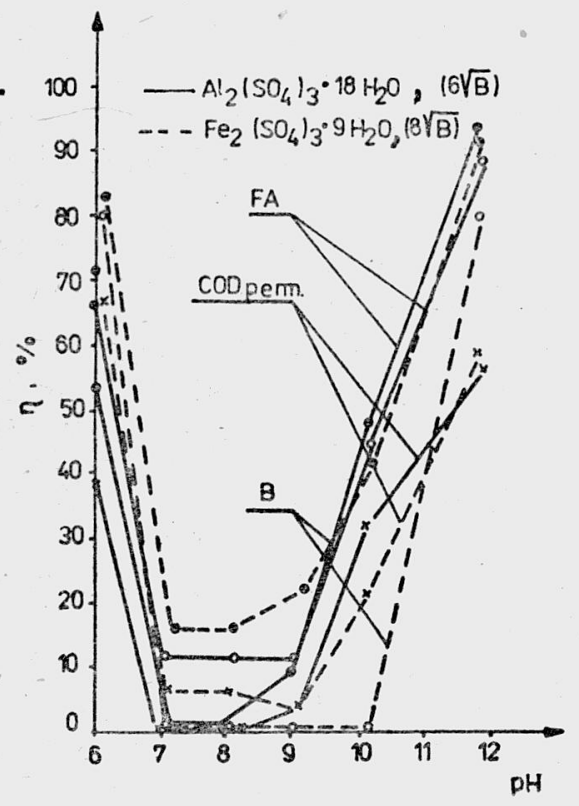

Fig. 1. Efficiency of alum or ferric sulphate coagulation versus $\mathrm{pH}$

Rys. 1. Skuteczność koagulacji siarczanem glinowym lub żelazowym w zależności od $\mathrm{pH}$

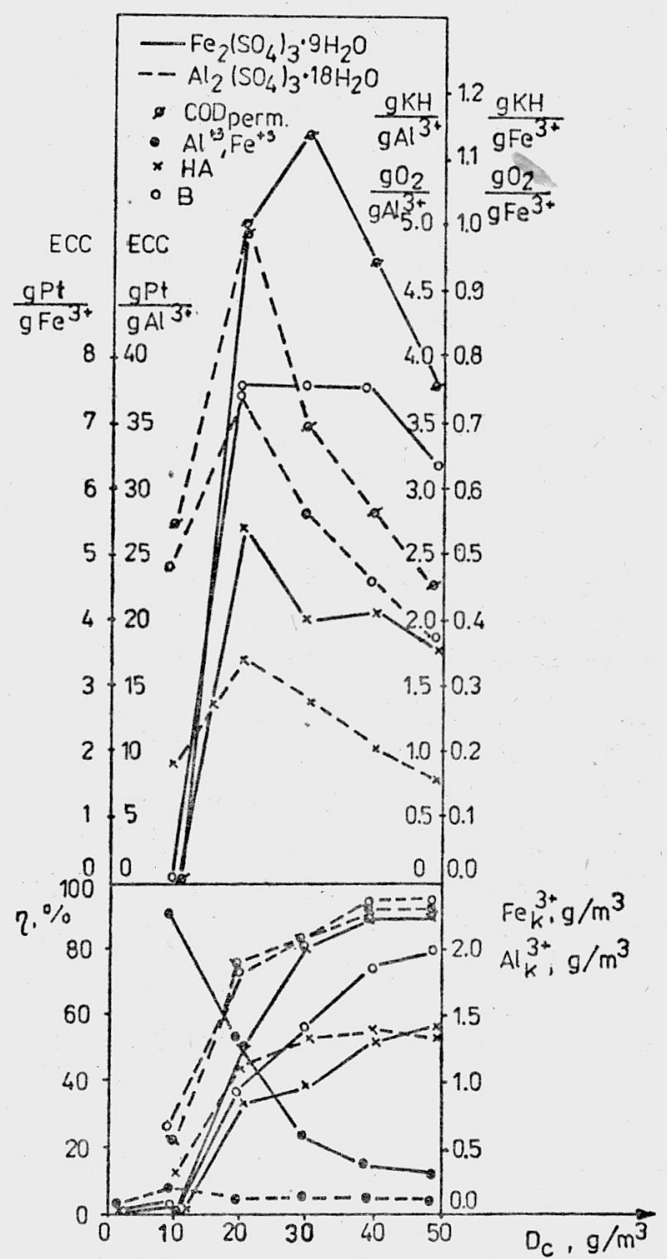

Fig. 2. Relationship between coagulant dose and process efficiency

Rys. 2. Zależność efektywności procesu od dawki koagulanta 
as $8 \sqrt{B}$ ) amount to $73.8 \mathrm{~g} / \mathrm{m}^{3}$ and $71.6 \mathrm{~g} / \mathrm{m}^{3}$, respectively. At an optimum $\mathrm{pH}$ one half of this dose, i.e. about $4 \sqrt{B}$, may be satisfactorily employed, thus the dose is reduced to some $40 \mathrm{~g} / \mathrm{m}^{3}$. The application of doses lower than the required ones, especially in the case of ferric coagulants, yields insufficient destabilization of organic colloids and the presence of coloured ferric-humic acid chelates in the effluent. The dependence of ECC on alum or ferric salt doses is shown in fig. 2. Comparison of removal efficiency indicates that in the process of organic matter removal $\mathrm{Al}^{3+}$ ions are more effectively used than $\mathrm{Fe}^{3+}$ ions Thus, $40 \mathrm{~g} / \mathrm{m}^{3}$ dose of coagulants (their sulphates), $0.938 \mathrm{mg} \mathrm{Fe}{ }^{3+}$ and $0.353 \mathrm{mg}$ $\mathrm{Al}^{3+}$ are required to remove $1 \mathrm{mg}$ of humic acids.

The investigations of ifp fulvic acid removal (which is far more difficult than that of humic or hymatomelanic acids) confirm the $\mathrm{pH}$-dependence of the process (fig. 3). They also indicate that the alum coagulant yields a better removal of coloured matter at a lower dosage as compared to the ferric coagulant. The application of ferric sulphate at a non-optimum $\mathrm{pH}$ and an insufficient dosage brings about an evident increase of colour (fig. 3), which is due to the formation of coloured ferric-fulvic chelates. No colour increase was observed when alum coagulant was employed, even though the residual concentration of aluminium (following completion of coagulation and 2-hour sedimentation) was high $\left(2.5 \mathrm{~g} \mathrm{Al}^{3+} / \mathrm{m}^{3}\right)$. This is an indication that if aluminium-fulvic acid complexes are formed, they will be colourless.

Analysis of experimental data showed that fulvic acids were stable and remained in the aqueous solution at $6<\mathrm{pH}<10$. High removal efficiency was achieved at $\mathrm{pH}=6.0$ (which is optimal for the coagulation of organic colloids) and $\mathrm{pH}=11.8$ (which is characteristic of the co-precipitation of fulvic acids and $\mathrm{Mg}(\mathrm{OH})_{2}$ ). This indicates that fulvic acids - a water-soluble fraction of humic substances - are responsible for the decreased coagulation efficiency in removing organics from aqueous solutions at $6.0<\mathrm{pH}<10.0$; they also decrease the rusability of ferric sulphate in the treatment of natural water containing humic substances.

5.3. RELATIONSHIP BETWEEN RESIDUAL CONCENTRATIONS OF $\mathrm{Al}^{3+}$, $\mathrm{Fe}^{3+}$ AND HUMIC ACIDS

Interpretation of the experimental results shows that the final content of humic acids strongly influences the residual concentrations of $\mathrm{Al}^{3+}$ or $\mathrm{Fe}^{3+}$ at the $\mathrm{pH}$ range under study. This means that $\mathrm{Al}^{3+}$ and $\mathrm{Fe}^{3+}$ cations act in two ways: as coagulants and coordinating ions for humic substances. The determined correlations between residual $\mathrm{Al}^{3+}$ or $\mathrm{Fe}^{3+}$ concentrations and humic acids are linear and may be expressed as follows:

$$
\begin{aligned}
& {\left[\mathrm{Fe}_{k}^{3+}\right]=0.435+0.212\left[\mathrm{HA}_{k}\right], \mathrm{g} / \mathrm{m}^{3}, r=0.795, p \gg 99.9,} \\
& {\left[\mathrm{Al}_{k}^{3+}\right]=0.272+0.116\left[\mathrm{HA}_{k}\right], \mathrm{g} / \mathrm{m}^{3}, r=0.84, p \gg 99.9 .}
\end{aligned}
$$


A combined removal of aluminium ions associated with humic substances may be also inferred from the fact that the residual concentrations of $\mathrm{Al}^{3+}$ (which in an alkaline medium occur predominantly in the form of $\mathrm{Al}(\mathrm{OH})_{4}^{-}$)) are lower when the solutions contain humic substances and do not decrease in absence of these substances (fig. 4). In ferric sulphate coagulation the presence of organic ligands also creates favourable conditions for the reduced concentration of residual $\mathrm{Fe}^{3+}$ ions in the treated solution.

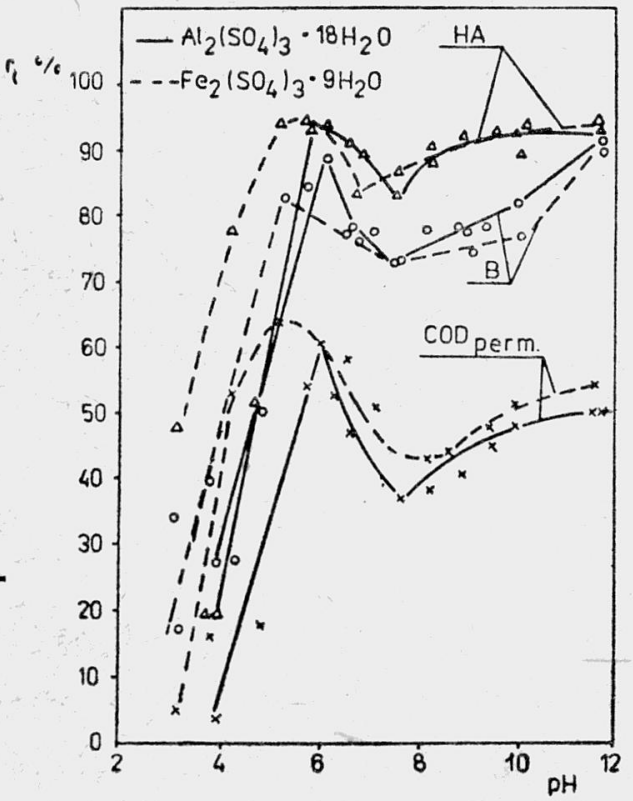

Fig. 3. FA removal efficiency versus $\mathrm{pH}$ Rys. 3. Skuteczność usuwania kwasów fulwowych w zależności od $\mathrm{pH}$

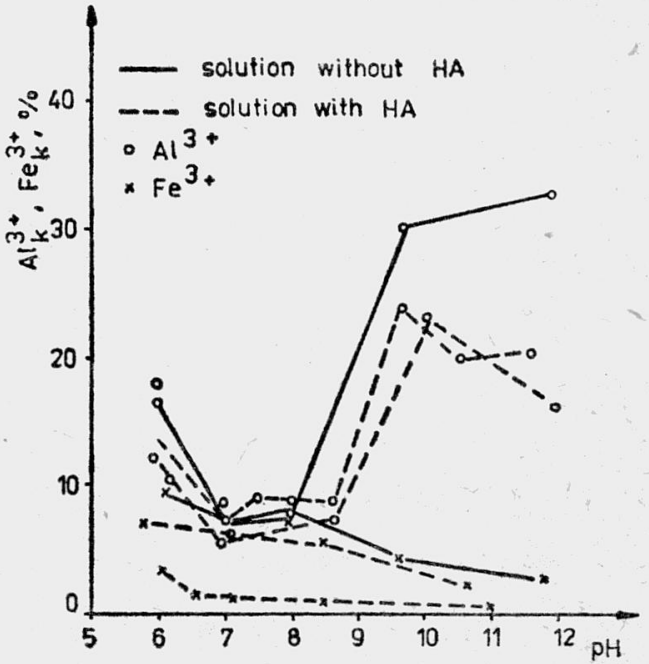

Fig. 4. Effect of $\mathrm{HA}$ in water being treated on $\mathrm{Al}_{k}^{+3}$ or $\mathrm{Fe}_{k}^{+3}$ concentration

Rys. 4. Wpływ kwasów humusowych na pozostałe stężenie jonów $\mathrm{Al}_{k}^{+3}$ i $\mathrm{Fe}_{k}^{+3}$

\section{CONCLUSIONS}

1. Coagulation involving alum or ferric salts yields a high degree of humic acid removal. To achieve high efficiencies at the lowest possible coagulant doses it is necessary that $\mathrm{pH}$ be about 6.0.

2. Application of optimal coagulant doses accounts for a complete destabilization of negative organic colloids. At lower doses, particularly of ferric salts, coloured complexes are produced. That is why ferric sulphate cannot be recommended as coagulant in the treatment of natural waters polluted with humic substances, especially with fulvic acids. 
3. When fulvic acids are present in the water to be treated, very poor coagulation effects are obtained at $\mathrm{pH}$ range $6.0<\mathrm{pH}<10.0$ (which is the most favourable for their stabilization); furthermore, in the presence of fulvic acids the degree of organic matter removal is lower.

4. The doses of coagulants (both ferric sulphate and alum) required to remove pure-for-analysis humic acids (which consist predominantly of humic and hymatomelanic acids) do not exceed those calculated from the formula $D=8 \sqrt{B}$. In the presence of humic acids isolated from peat (which contain approximately $25 \%$ of fulvic acids), at a $\mathrm{pH}$ of about 9.5 , ferric sulphate doses up to $8 \sqrt{B}$ are insufficient to yield the desired coloured matter removal.

5. The $\mathrm{Al}^{3+}$ and $\mathrm{Fe}^{3+}$ ions act as coagulants and coordinating ions for metalorganic complexes and are removed in combination with organic ligands but the former were more efficient in organic (especially coloured) matter removal.

\section{REFERENCES}

[1] Bizozor S., Badania nad usuwaniem prekursorów trójhalometanów z wody do picia, Mat. Konf. VII Krajowej Konf. Nauk.-Techn. „Zagadnienia zaopatrzenia w wodę miast i wsi", p. 68, Poznań 1980.

[2] Biack A. P., Singley J. E., Whittle G. R., Stoichiometry of the coagulation of colourcausing organic compounds with ferric sulphate, JAWWA 1963, p. 1347.

[3] Breemen A. W. et al, The fate of fulvic acids during water treatment, Water Research, $1979 / 8$, p. 771 .

[4] Christmah R. F., Black A. P., Characteristics of fulvic acids, JAWWA 1963/7, p. 897.

[5] Creary J. J., Suom Yrnk V. L., Characterization and activated carbon adsorption of several humic substances, Water Research, 1980/2, p. 151.

[6] Haberer K., Normann S., Über die Bedeutung des $p H$-Wertes bei der Flockung organisch belasteter Wässer, GWF-Wässer/Abwasser 1977, p. 118.

[7] Klute R., Neis U., Banz J., Untersuchungen zur Kinetik der Flockung mit Polyelektrolyten in Gegenwart von Huminsäure, Vom Wasser, Vol. 53, (1979), p. 203.

[8] Kononowa M., Substancje organiczne gleby, ich budowa, wlaściwości i metody badań, PWRiL, Warszawa 1968.

[9] Kowal A. L., Kowalski T., Wplyw stopnia biochemicznego rozkladu zwiqzków organicznych w rzece Odrze na efektywność uzdatniania do celów przemyslowych, Report of the Institute of Environment Protection Engineering, Technical University of Wrocław, 1981, I-15/SPR-19/81.

[10] Kowal A. L., Świderska-Bróż M., Wplyw odczynu na skuteczność usuwania barwy $i$ uilenialności w procesie koagulacji, GWiTS, 1979/9, p. 272.

[11] LEIDNER H. et al., Exclusion chromatography with carbon detection a tool for further characterization of dissolved organic carbon, Water Research, Vol. 15 (1981), No. 4.

[12] Monogravite F. J., Buzell T. D. et al., Removal of humic acids by coagulation and microflotation, JAWWA, 1975/2, p. 88.

[13] NARKIS N., REBHUN M., Stoichiometric relationship between humic and fulvic acids and flocculants, JAWWA $1977 / 6$, p. 325 .

[14] ŚWIDERSKA-BRóż M., Interakcja zwiqzków humusowych i niektórych metali cięzkich $w$ roztworach wodnych oraz procesach ich oczyszczania (to be published in: "Prace Naukowe 
Instytutu Inżynierii Ochrony Środowiska Politechniki Wrocławskiej, Seria: Monografie").

[15] Trojanowski J., Przemiany substancji organicznych w glebie, PWRiL, Warszawa 1973.

\section{USUWANIE SUBSTANCJI HUMUSOWYCH W PROCESIE KOAGULACJI}

Przedstawiono skuteczność usuwania kwasów humusowych w procesie koagulacji i podezas dwugodzinnej sedymentacji. Określono optymalny zakres pH przy usuwaniu roztworów wodnych kwasów huminowych i fulwowych $(\mathrm{pH}=6,0$ lub $>10)$. Badania wykazały, że: 1) siarczan żelazowy jest mniej skutecznym koagulantem niż siarczan glinowy, 2) jony $\mathrm{Al}^{+3}$ i $\mathrm{Fe}^{+3}$ zachowują się jak koagulanty i jony koordynujące i są usuwane razem z kwasami humusowymi.

\section{BESEITIGUNG VON HUMUSSUBSTANZEN IM KOAGULATIONSVERFAHREN}

Humussubstanzen werden im Koagulationsverfahren mit zweistündiger Sedimentation beseitigt und der Wirkungsgrad beider Prozesse wird beurteilt. Der optimale pH-Wert für die Beseitigung von Humin- und Fulvensäuren aus wässerigen Lösungen fällt in den Bereich von 6,0 oder 10,1 .

Die Versuchsergebnisse weisen darauf hin, daß Eisensulfat zu einem geringeren Koagulationseffekt beiträgt, als es bei der Anwendung von Alaun der Fall ist, und daß $\mathrm{Al}^{3+}$ und $\mathrm{Fe}^{3+}$ als Flockungsmittel zugleich den Koordinationskern für metallorganische Komplexe bilden, um mit der Huminsäure gemeinsam beseitigt zu werden.

\section{УДАЛЕНИЕ ГУМУСОВЫХ ВЕЩЕСТВ В ПРОЦЕССЕ КОАГУЛЯЦИИ}

Представлена эффективность удаления гумусовых кислот в процессе коагуляции и во время двухчасовой седиментации. Определён оптимальный диапазон рН при удалении из водных растворов гуминовых кислот и фульвокислот ( $\mathrm{pH}=6,0$ или > 10). Исследования показали, что: 1$)$ сульфат железа (III) является менее эффективным коагулянтом, чем сульфат алгоминия, 2) ионы $\mathrm{Al}^{+3}$ и $\mathrm{Fe}^{+3}$ ведут себя как коагулянты и координирующие ионы и удаляются вместе с гумусовыми кислотами. 